\title{
THE DECREASE IN ULTRA-VIOLET AND TOTAL RADIATION WITH USAGE OF QUARTZ MERCURY VAPOR LAMPS
}

\author{
By W. W. Coblentz, M. B. Long, and H. Kahler
}

CONTENTS

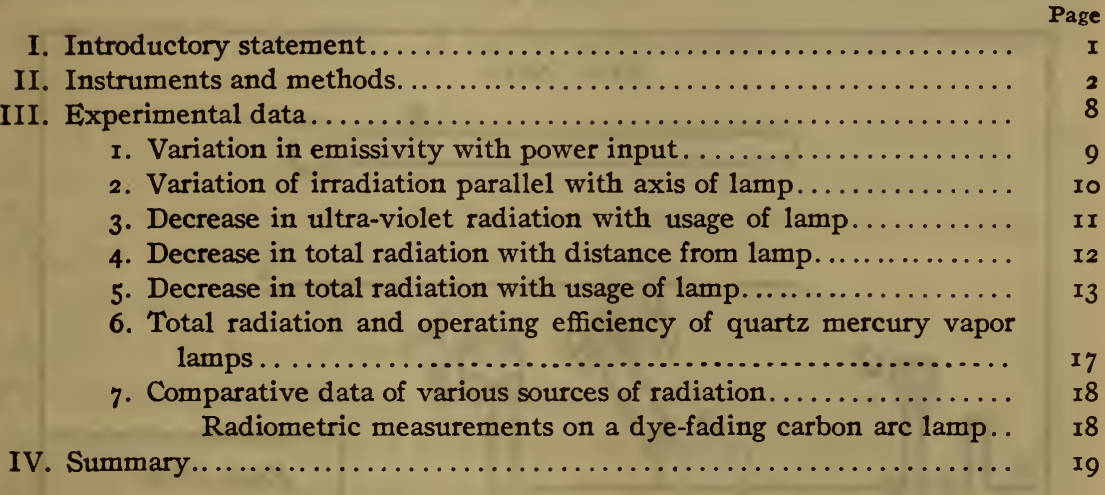

\section{INTRODUCTORY STATEMENT}

The radiations from quartz mercury vapor lamps are being used extensively in accelerating photochemical actions, as a bactericide in sterilizing water, as a therapeutic agent, in dye-fading tests, etc.

The violet and ultra-violet rays, as distinguished from the infra-red rays, appear to have a marked effect in accelerating chemical action, and there has arisen among manufacturers of paper, dyes, cloth, rubber goods, paints, etc., a distinct need for a source of ultra-violet radiation of high intensity which does not decrease with usage.

It is well known that the intensity of the radiation (especially the ultra-violet component) from quartz mercury vapor lamps decreases greatly with usage. This decrease in intensity with usage has been determined qualitatively by several experiments, ${ }^{1}$ using physical, chemical, and biological tests. But no exact quantitative data appear to be available showing how rapidly

1 Vaillant, Compt. Rend., 142, p. 8r; 1906; Bordier, Arch. d'Elect. Medicale, 18, p. 390, rgro; Courmont and Nogier, Compt. Rend., 152, p. 1746; 19xx.

$78572^{\circ}-18-1$ 
and how much the intensity decreases with time of operation of the lamp.

Some months ago the problem was presented, first, to devise methods for determining quantitatively this decrease in intensity of emission with usage, and, second, to make preliminary measurements on radiant power-life tests of quartz mercury vapor lamps.

\section{INSTRUMENTS AND METHODS}

In considering various methods for observing the radiations emitted by quartz mercury vapor lamps it was apparent that photography would not give reproducible quantitative results,

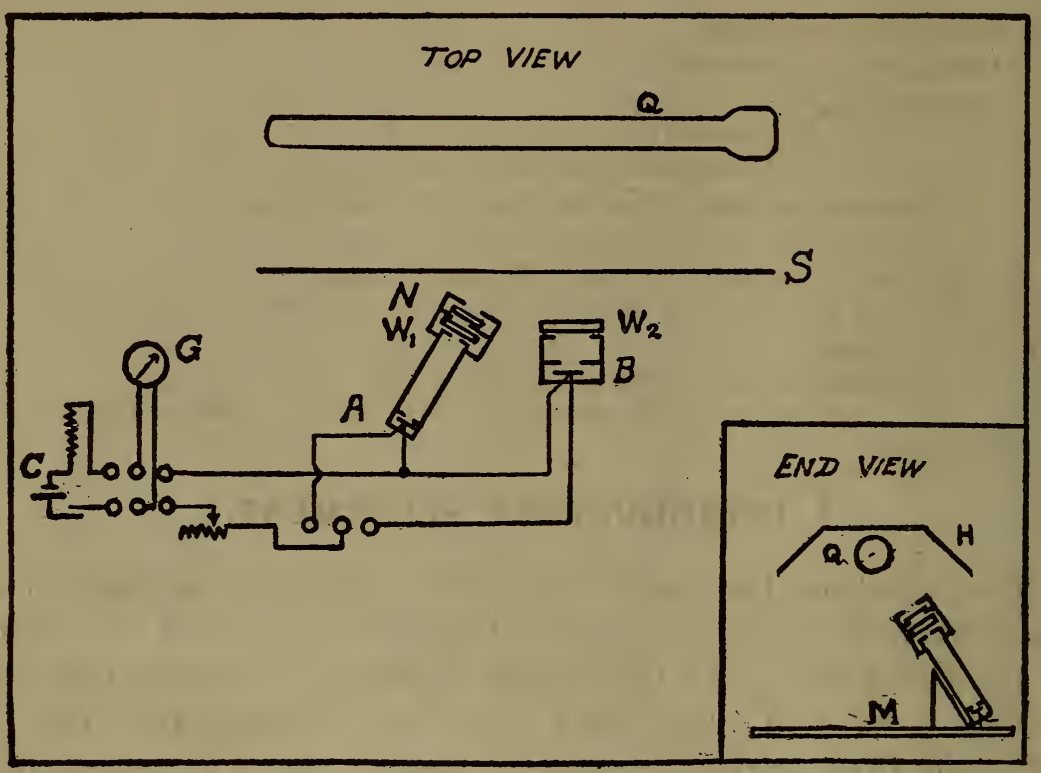

FIG. I.-Arrangement of apparatus for measuring the radiation from quartz mercury vapor lamps

while photometric methods are not sufficiently comprehensive to take into consideration the decrease in intensity of the ultraviolet component of the radiations from the lamp.

The logical method of procedure is to measure the intensity of the radiations in absolute units by using a nonselective radiometer (e. g., thermopile) which can be calibrated by means of a standard of radiation. ${ }^{2}$ This method was employed throughout the present investigation. 
The radiometer used was a thermopile of bismuth. silver, ${ }^{3}$ which was covered with a quartz window $(t=0.15 \mathrm{~mm})$ to prevent unsteadiness caused by air currents. The thermopile was placed in a mounting, $M$, Fig. $I$, which could be secured in a fixed position, facing the lamp. When not in use, this radiometer outfit was removed to a secure place free from dust and likelihood of injury.

The general arrangement of the apparatus is shown in Fig. $\mathrm{I}$, in which $Q$ is the quartz mercury lamp, with its protecting hood $H$. The shutter $S$ permits the radiations from the lamp to fall upon the thermopiles $A$ and $B$. The absorption cells of water are at $W_{1}$ and $W_{2}$. The Noviol absorption glass is mounted at $N$.

The electric current which was generated by the thermopile was measured by means of an iron-clad Thomson galvanometer, ${ }^{4} G$, Fig. I; though for most of the work a sensitive d'Arsonval galvanometer would have served the purpose.

Apparatus ( $C$, Fig. I) was provided for testing the current sensitivity of the galvanometer, which varied from day to day. The radiation sensitivity, in absolute units (gram-calories), of the thermopile-galvanometer combination was determined at frequent intervals by exposing the thermopile to the standard of radiation just mentioned. The sensitivity of the radiometric apparatus was such that for the standard galvanometer current sensitivity of $i=5 \times 10^{-10}$ ampere, a deflection of $\mathrm{I} \mathrm{cm}$ (caused by radiation from the standard lamp) represented an energy flux of 2.21 microwatt per square centimeter. Multiplying the observed galvanometer deflection by this factor, and knowing the distance intervening between the lamp and the thermopile, it was an easy matter to specify the intensity of the energy (the radiant flux) incident at the point where the measurement was made. This distance was $40 \mathrm{~cm}$ from the axis of the lamp and equidistant from the effective ends of the quartz glass tube.

Under normal operation the quartz glass tube of a mercury vapor lamp becomes heated to a dull red, thus emitting considerable infra-red radiation of wave lengths greater than $2 \mu$ ( $\mu=0.00 \mathrm{Imm})$. On the other hand, the emission spectrum of the mercury vapor consists of strong lines which abound in the ultra-violet, visible, and the infra-red spectrum, extending to about $\mathrm{r} .6 \mu$, as shown in Fig. 2, in which the ultra-violet measurements were taken from 
a paper by Souder. ${ }^{5}$ The visible and infra-red measurements were obtained from a paper by Coblent $z,{ }^{6}$ corrections having been made for slit widths and for power input such as used in the lamps employed in the present work. The three crosses $(x x x)$ show the distribution of intensities on a lower power input, under which condition the green mercury line is more intense than the yellow lines. There is, of course, considerable energy radiated in the form of a continuous spectrum, which would affect the relative proportions in the visible and in the ultra-violet and which is not indicated in these measurements. The emission lines, of wave lengths greater than I. $6 \mu$, contribute but little to the total radiation emitted by the mercury vapor.

A cell, I $\mathrm{cm}$ in thickness, having thin $(1.5 \mathrm{~mm})$ windows of quartz and containing distilled water (which is opaque to radiations

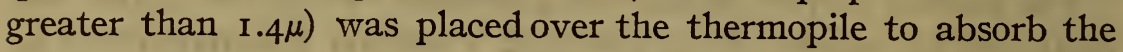

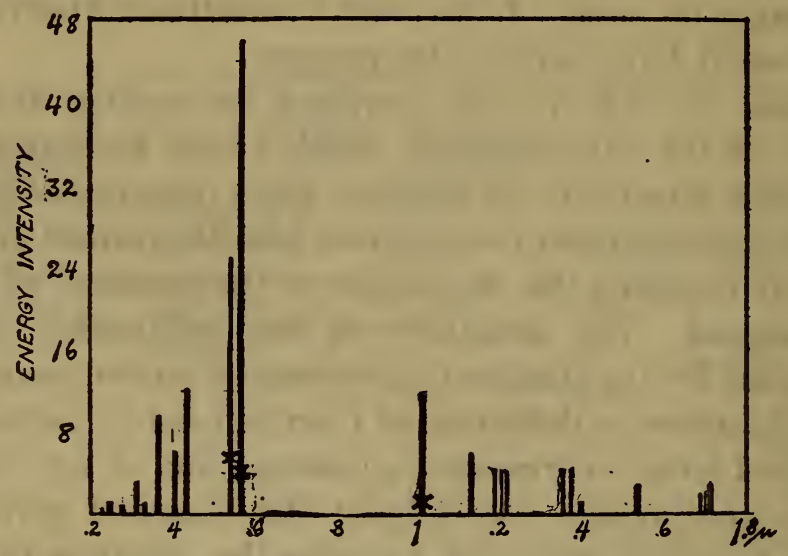

FIG. 2.-Energy distribution in the spectral lines emitted by quartz mercury vapor lamps

radiations emitted by the quartz glass tuibe. This cell is transparent to ultra-violet rays and its use increases the accuracy of the observations by absorbing infra-red radiations emitted by the electrodes and the quartz tube, which vary greatly in temperature, depending upon the temperature of the surrounding air, etc.

As already stated, the energy radiated by a quartz mercury vapor lamp suffers depletion of the ultra-violet component with usage of the lamp. This is attributable to discoloration (blackening) and devitrification of the bulb which absorbs the ultraviolet more strongly than the visible rays. ${ }^{7}$

${ }^{5}$ Souder, Phys. Rev., 8, p. 316; 1916.

6 The Bulletin, 9, p. $96,:$ I $^{\mathrm{I}}{ }_{2}$. The wave lengths are from Paschen, Ann. der Phys., 27, p. 558; 1908.

${ }^{7}$ Quartz.glass changes into crystalline quartz (tridymite) when heated to about $900^{\circ}$. 
From the experimental data at hand, it would appear that (at the expense of decreasing somewhat the total energy radiated) there would be a marked increase in the useful life and luminous efficiency by operating the lamp at a lower temperature. This would decrease the vaporization of the tungsten electrodes and, hence, the blackening of the walls of the lamp.

It is well known that with increase in energy input the luminous efficiency of a mercury vapor lamp increases and passes through a maximum value. ${ }^{8}$

As was shown in a previous investigation ${ }^{8}$ this phenomenon is attributable to the more rapid increase in infra-red energy emission (with increase in energy input) as compared with the emission of visible and ultra-violet rays.

For high values of energy input the ultra-violet and visible emission lines are relatively less intense than the infra-red lines, while for a low-energy input the reverse condition is true, viz, the visible and ultra-violet rays are relatively the more intense, as illustrated by the crosses $(x x x)$ in Fig. 2.

Hence in measuring the decrease in intensity of the ultra violet as compared with the visible radiations, with usage of the lamp, it was necessary to resort to some expedient which would avoid the above-mentioned change in relative intensities of the visible and ultra-violet with change in energy input. For, at the beginning of the investigation, it was not known what changes with usage the lamps might undergo in their volt-ampere characteristics, in their evacuation, etc.

The simplest method of measuring the decrease in the violet component with usage of the lamp would be to use a screen (I) which transmits all the ultra-violet and absorbs all the visible and infra-red rays, or (2) which absorbs all the ultra-violet and transmits all the visible and the infra-red. No such ideal screen is known, but a deep-yellow glass (Corning Noviol, shade B) which absorbs all the ultra-violet rays shorter than $\lambda=0.4 \mu$ was found to answer the purpose. ${ }^{10}$

In a preliminary investigation of the transmission of the radiations from the quartz mercury vapor lamps through glasses of various colors, with variation in energy input into the lamps (see Table I), it was found that this sample of yellow glass was

8 Küch and Retschinsky, Ann. der Phys., (4) 20, p. 563; 1906.

This Bulletin, 9, p. 96; 19r2.

10 The transmission of this glass is given in this Bureau's Technologic Paper No. 93, 2d ed., p. 17, Fig. Ia See also this Bulletin, 14, p. 653: 1918. 
unique in having, within the errors of observation, the same transmission for a variation in energy input of 100 to 200 watts. This simplified the experimental work, for it was then unnecessary to operate the lamp at the same energy input when making the transmission measurements from time to time, ard any change in the transmission of this glass with usage of the lamp would be attributable to a change in the quality of the radiations emitted by (transmitted through the walls of) the lamp. A progressive decrease in the ultra-violet radiation, with usage of the lamp, would cause a progressive increase in the percentage of the total radiation which can pass through the yellow glass.

TABLE 1.-Transmission of the Radiations of Wave Lengths Less than $1.4 \mu$ from R. U. V. Quartz Mercury Vapor Lamp Through Glasses of Various Colors, with Variation in Energy Input

[A. O. C.=American Optical Co.; C. G. W.=Corning Glass Works]

\begin{tabular}{|c|c|c|c|c|c|c|c|c|}
\hline \multirow{2}{*}{ Color of glass } & \multirow{2}{*}{ Trade name } & \multirow{2}{*}{ Source } & \multicolumn{6}{|c|}{ Energy input in watts } \\
\hline & & & 100 & 200 & 260 & 400 & 540 & 615 \\
\hline Colorless... & Lab. No. 58.......... & A.O.C. & 51.5 & 48.0 & & 44.6 & 43.4 & 44.2 \\
\hline Red............... & Selenium .......... & C.G.W. & 4.9 & 5.2 & $\cdots$ & 6.2 & 7.3 & 8.2 \\
\hline Orange............... & $634 \ldots \ldots \ldots \ldots . .$. & C.G.W. & 11.2 & 12.5 . & ...... & 14.7 & 16.4 & 17.2 \\
\hline Amber....... & & B.S. & 13.2 & 12.7 & & 13.5 & 13.6 & 14.5 \\
\hline Blue-green.......... & Lab. No. 59........ & A.O.c. & 23.4 & 20.7 & ..... & 19.8 & 18.8 & 18.5 \\
\hline Purple .............. & G55 A62............ & C.G.W. & 14.3 & 16.0 & ..... & 17.9 & 18.1 & 17.7 \\
\hline Yellow .............. & Noviol, shade B... & C.G.W. & 31.2 & 31.1 & ....... & 30.9 & 32.5 & 32.2 \\
\hline & & & & & 28.7 & & & 29.0 \\
\hline
\end{tabular}

This is so because, in passing out through the walls of the lamp, the ultra-violet radiations suffer a proportionately greater reduction in intensity than the (visible) radiations which are not absorbed by the yellow glass. A determination of the transmission consists in noting the galvanometer deflections when the plate of yellow glass intervenes between the thermopile and the lamp and when no glass intervenes. The ratio of these two deflections is a measure of the transmission, which increases with decrease in the ultra-violet rays.

The decrease of the ultra-violet component was determined by making transmission observations upon the radiations emitted from a length of about $5 \mathrm{~cm}$ of the central part of the quartz lamp tube, in order to avoid the radiations from the incandescent electrodes. For this purpose a bismuth-silver thermopile, having a circular receiver ${ }^{11} 5 \mathrm{~mm}$ in diameter, was mounted in a 
suitable brass tube, $A$, Fig. I, which admitted radiations coming only from the central part of the lamp. A I cm cell, $W_{1}$, Fig. I, having thin quartz windows (20 $\mathrm{mm}$ opening) and containing distilled water, absorbed most of the radiations from the hot quartz tube, but transmitted the ultra-violet rays. The Noviol and other glasses used in the transmission tests were placed in front of the water cell (at $N$, Fig. I) and any change in the transmission with age of the lamp would be ascribable to a decrease in the ultra-violet component of the radiations passing through the walls of the lamp.

The decrease in total radiation with usage was determined by measuring the radiations emanating from the whole lamp, including radiations unavoidably reflected from the hood, $H$, Fig. I, which was used over the lamp. For this measurement a bismuth-silver thermopile, $B$, Fig. I, having a linear receiver, 2 by I $5 \mathrm{~mm}$, long axis at right angles with the long axis of the lamp, was used. No water cells with quartz windows of suitable size being available at the time when the work was undertaken, a I cm cell, with crown-glass windows, $W_{2}$ (35 mm opening), was used to absorb the infra-red rays. This second radiometric outfit gave a partial check on the observations made with the Noviol absorption glass. Of course the total radiation was observed also on the $5 \mathrm{~cm}$ length of the lamp, but no record was kept of the energy input of the lamp, the galvanometer sensitivity, the distance of the thermopile from the lamp, etc., which data would be required in reducing the data obtained with the thermopile (with circular receiver) used in measuring the ultra-violet component.

The lamps under investigation were mounted in a light-tight inclosure, which was kept thoroughly ventilated, without producing a strong draft over the lamps.

In order to protect the eyes from injury when adjusting the thermopiles for making radiometric measurements, the attendants wore deep amber-colored glasses, Corning Noviweld, shade $6{ }^{12}$. As a further precaution against injury from reflected light, the inside of the inclosure and the mountings were painted black. This is a precaution which should be observed in dye-fading and similar tests involving the use of quartz mercury vapor lamps. The injurious effects of ultra-violet light are usually not felt until some hours have elapsed after exposure to these rays.

${ }^{12}$ See this Bureau's Technologic Paper No. 93, on glasses for protecting the eyes from injurious radiations. $78572^{\circ}-18-2$ 


\section{EXPERIMENTAL DATA}

The data discussed under this caption were obtained on lamps purchased from the Cooper-Hewitt Electric Co. and from the R. U. V. Co. ${ }^{13}$.

In the discussion of the data these two types of lamps are referred to as C. H. and R. U. V. Of the former, r IO-volt and 22Ovolt lamps were available. Of the latter type only 220-volt lamps were obtainable.

These lamps, with their auxiliary ballast resistances were operated on the specified voltage and currents. A watt-hour meter was connected in the circuit of each lamp, and, on the days when the radiation measurements were made, a wattmeter, an ammeter, and sometimes a voltmeter were used to obtain data on the electrical characteristics of the lamp. The electrical characteristics of the lamp vary somewhat with the temperature of the surroundings.

The R. U. V. lamp is operated at a very high temperature, and the voltage-current relation is rather unstable. Because of this great fluctuation in power input it was necessary to watch the wattmeter and make radiometric measurements when the wattmeter indicated a certain value, say 6 I 5 watts. The C. H. lamps did not fluctuate in energy input, other than that which resulted from fluctuation in the line voltage.

The lamps were not operated continuously and some ceased to function after 800 to 1200 hours of actual usage, owing to leakage of air into the bulb.

On continuous operation quartz mercury lamps are known to depreciate less rapidly-i. e., have a longer life-than when operated intermittently. The present data are, therefore, not to be considered as a "life test," as measured in the total number of hours a lamp may be operated. These lamps were in operation extending over a period of three and one-half months. As in the case of incandescent lamps, the question will probably arise as to what constitutes the useful life of a quartz mercury vapor lamp. In the present case the lamps were used in dye-fading experiments (the radiometric measurements in all cases being incidental), and the use of one lamp was discontinued after its total radiation intensity had decreased to one-third its original value, although mechanically the burner appeared to be in good condition.

${ }^{13}$ Cooper-Hewitt Electric Co., Hoboken, N. J. The R. U. V. Co., x50 Broadway, N. Y. 


\section{VARIATION IN EMISSIVITY WITH POWER INPUT}

The lamps being operated on the city power circuit were subject to fluctuations in power input. The total radiation from the lamp (through the water cell) with variation in power input was, therefore, determined at the start by-operating it on a storage battery. The data so obtained (see Fig. 3) were used in reducing the observations of the total radiation, with usage, to a standard power input, say 400 watts for the C. H. lamps and 600 watts for the R. U. V. lamps. For this purpose the experimental curves

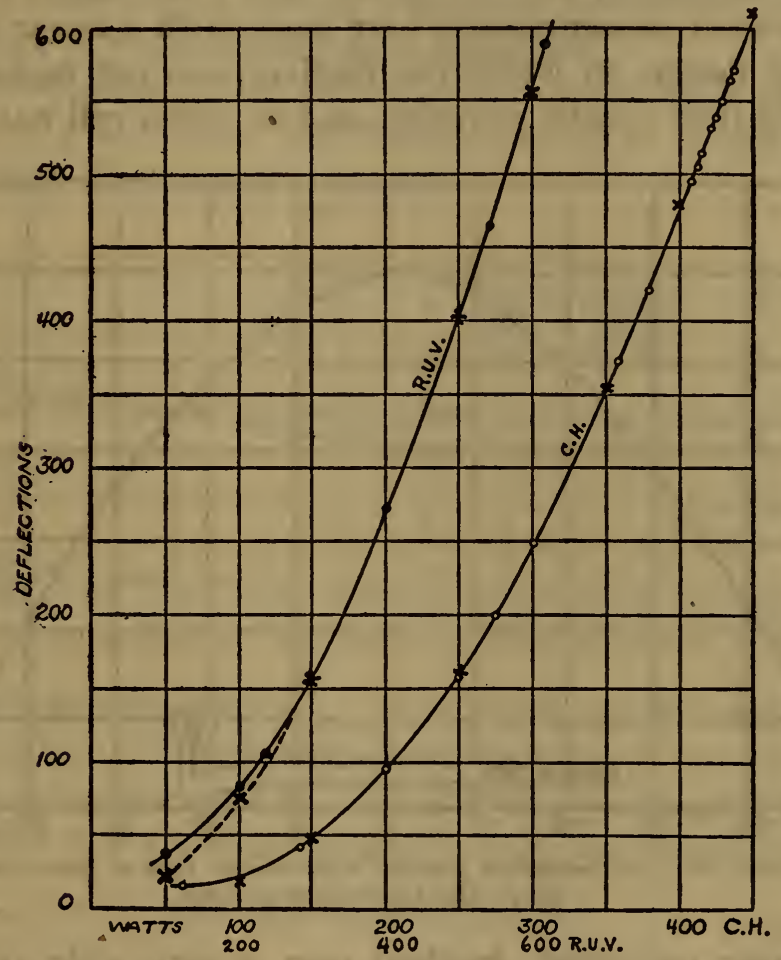

FIG. 3.-Variation in total radiation emitted with variation in power input

illustrated in Fig. 3 are closely represented by the formula $E=K W^{\mathbf{x}}$ where $E$ is the energy of wave lengths less than $1.4 \mu$ emitted by the quartz mercury vapor, $K$ is a constant, and $W$ is the power input in watts.

For one of the R. U. V. quartz mercury lamps studied (upper curve Fig. 3), the formula $E=0.00462 W^{1.83}$ was found to fit the observations to within less than I per cent over a range of power input from 300 to 600 watts. As shown by the crosses in Fig. 3, for a power input of 200 watts or less the computed values differ considerably from the observed. 
For the C. H. lamp (lower curve, Fig. 3) the formula $E=$ $0.000457 W^{2 \cdot 314}$ was found to fit the observations to within I per cent over a range of 150 to 400 watts of power input, giving values which are 2 per cent low at roo watts and 2 per cent high at $45^{\circ}$ watts, as shown by the crosses in the lower curve, Fig. 3 .

\section{VARIATION OF IRRADIATION PARALLEL WITH AXIS OF THE LAMP}

In connection with the dye-fading tests, it was of interest to determine the intensity of the irradiation along a line parallel with and at a distance of $40 \mathrm{~cm}$ from the axis of the lamp.

The present measurements were made with a linear thermopile of special design, in which the receiver was not inclosed in the protecting tube usually provided, and no water cell was used. In

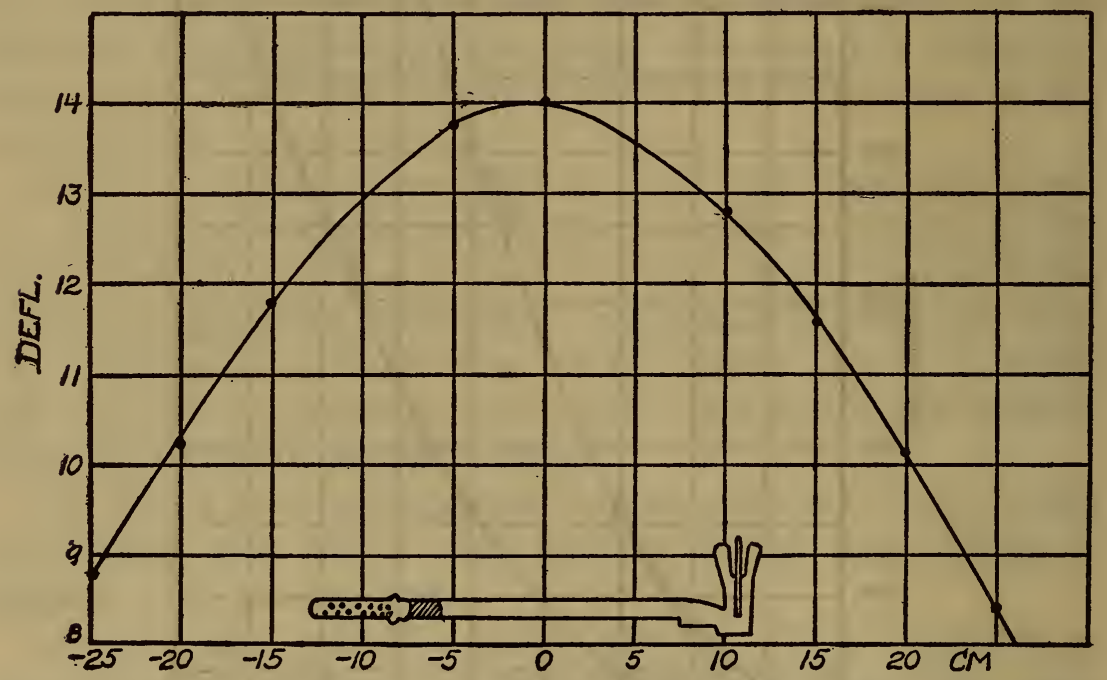

FIG. 4.-Variation of illumination parallel with axis of tube of quartz mercury vapor lamp; also illustration of lamp

this manner radiations, incident over a very wide angle, could fall upon the receiver, which moved in ways, which were placed parallel with the axis of the lamp.

The radiometric observations were made upon an $R$. U. V. lamp, length about ${ }_{5} \mathrm{~cm}$, illustrated in the lower part of Fig. 4 . Measurements were made of the radiation intensity at what was judged to be the optical center of the lamp and at intervals of $5 \mathrm{~cm}$ to the right and left of this point. These measurements are illustrated in Fig. 4, in which the ordinates represent the intensities (the galvanometer deflections) observed at various points along the axis of the lamp. From this it appears that, for a 
length of about ro $\mathrm{cm}$, which constitutes the light-giving portion of the lamp, the intensity is fairly uniform.

\section{DECREASE IN ULTRA-VIOLET RADIATION WITH USAGE OF LAMP}

As already mentioned, the decrease in the ultra-violet radiation emitted by quartz mercury vapor lamps was determined by observing the transmission of these radiations (of wave lengths less than $\mathrm{r} .4 \mu$ ) through a sample of Noviol glass, ${ }^{14}$ shade $\mathrm{B}$, with usage of the lamp. These data are given in the next to the last column in Tables 3,4 , and 5 , which are published to illustrate the behavior of some of the lamps examined.

The transmission of this yellow glass is of the order of 29 to 30 per cent for a new lamp, and increases to 35 to 45 per cent, depending upon the usage of the lamp.

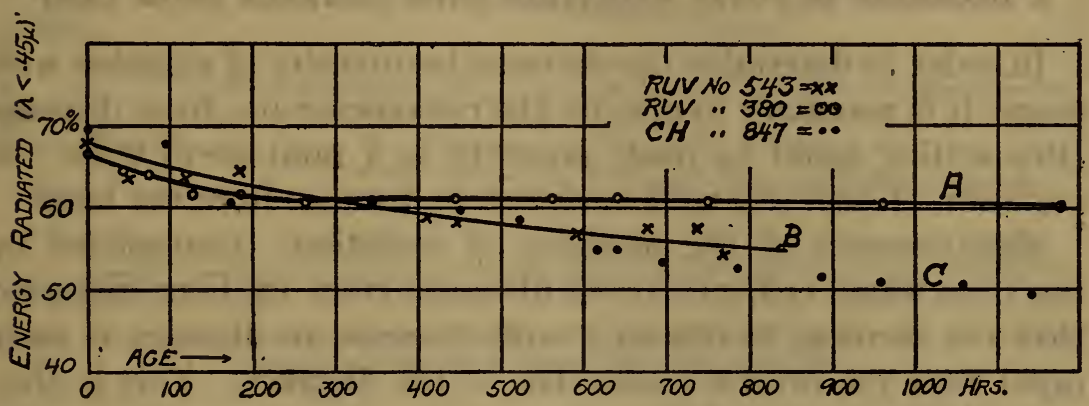

FIG. 5.-Decrease in ultra-violet radiation with usage of quartz mercury vapor lamps

The last column in Tables 3,4 , and 5 gives the per cent of ultraviolet radiation of wave lengths less than $0.45 \mu$ in the total radiation (of wave lengths less than $1.4 \mu$ ) emitted, with usage of the lamp. It is obtained from the transmission data (in the preceding column) on the basis that the ultra-violet $=100-\frac{T r}{0.9}$. The factor 0.9 is introduced to correct for absorption and reflection losses in the glass. In Fig. 5 is illustrated the decrease in ultra-violet radiation with usage of several quartz mercury vapor lamps. During the first 500 to 700 hours usage there was no marked difference in the per cent of ultra-violet emitted by these lamps. (See Table 6.)

It may be observed that the ultra-violet component of wave lengths less than $0.45 \mu$ amounts to about 67 per cent of the total radiation (of wave lengths less than $I .4 \mu$ ) emitted by the mercury vapor when using a new lamp, and decreases to 60 per cent or less after operating the lamp for some time. 
In the case of the C. H. lamp, Table 5 , the quartz tube had become tinged a faint brown, which seems to obstruct the ultraviolet rays. The R. U. V. lamps become discolored with a dark substance which is no doubt vaporized from the tungsten electrodes. This does not seem to obstruct the ultra-violet quite so much as the brown deposit, but tests on a larger number of lamps would be required to establish these observations as true in general.

As already mentioned, there is considerable infra-red radiation present as the result of heating of the electrodes and the supports of the lamp. The ultra-violet component is only about 20 per cent of the total radiation (of all wave lengths) emanating from the whole lamp.

\section{DECREASE IN TOTAL RADIATION WITH DISTANCE FROM LAMP}

In order to determine the decrease in intensity of emission with usage, it is necessary to operate the radiometer at a fixed distance (this setting could be made accurate to $I \mathrm{~mm}$ ) or to know the variation of intensity with variation in distance from the lamp.

Measurements of the intensity of radiations (transmitted by the I $\mathrm{cm}$ water cell) at various distances from the lamp indicated that the increase in intensity with decrease in distance is more rapid than the inverse square law of the distance. This is illustrated in Table 2 , in which column 2 gives the observed intensities and column 3 gives the computed intensities (using the distance $40 \mathrm{~cm}$ as the comparison point) on the basis of the inverse square law, which of course applies only to a point source. In this test the lamp, in its hood, was moved vertically over the thermopile, which had its receiver horizontal (the long axis being at right angles with) and at equal distances from the ends of the lamp.

TABLE 2.-Decrease in Intensity of total Radiation of Wave Lengths Less than $1.4 \mu$ with Distance from a 220-Volt C. H. Lamp

[Extrapolated values are in parentheses]

\begin{tabular}{|c|c|c|c|c|c|}
\hline \multirow{2}{*}{ Distance in millimeters } & \multicolumn{2}{|c|}{ Intensity } & \multirow{2}{*}{ Distance in millimeters } & \multicolumn{2}{|c|}{ Intensity } \\
\hline & Observed & Calculated & & Observed & Calculated \\
\hline $280 \ldots$ & n..... & 284 & $407 . \ldots \ldots \ldots \ldots$ & 134.5 & \\
\hline $300 \ldots$ & $(240)$ & 248 & $400 \ldots \ldots \ldots$ & (139) & 139 \\
\hline $338 . \ldots \ldots \ldots \ldots \ldots \ldots$ & 190.5 & 195 & $459 . \ldots \ldots \ldots \ldots \ldots \ldots$ & 105.5 & -....... \\
\hline $360 \ldots \ldots \ldots \ldots \ldots \ldots \ldots$ & (171) & 171.6 & $500 \ldots \ldots \ldots \ldots \ldots \ldots \ldots$ & 89.5 & 89.0 \\
\hline
\end{tabular}




\section{DECREASE IN TOTAL RADIATION WITH USAGE OF LAMP}

The decrease in the radiation of wave lengths less than $1.4 \mu$ emitted by quartz mercury vapor lamps was determined by means of a linear thermopile and I-cm water cell, placed at a distance of $40 \mathrm{~cm}$ from the lamp, as described on a preceding page.

Observational data for two R. U. V. lamps and one C. H. lamp (all of the 220-volt type) are illustrated in Fig. 6.

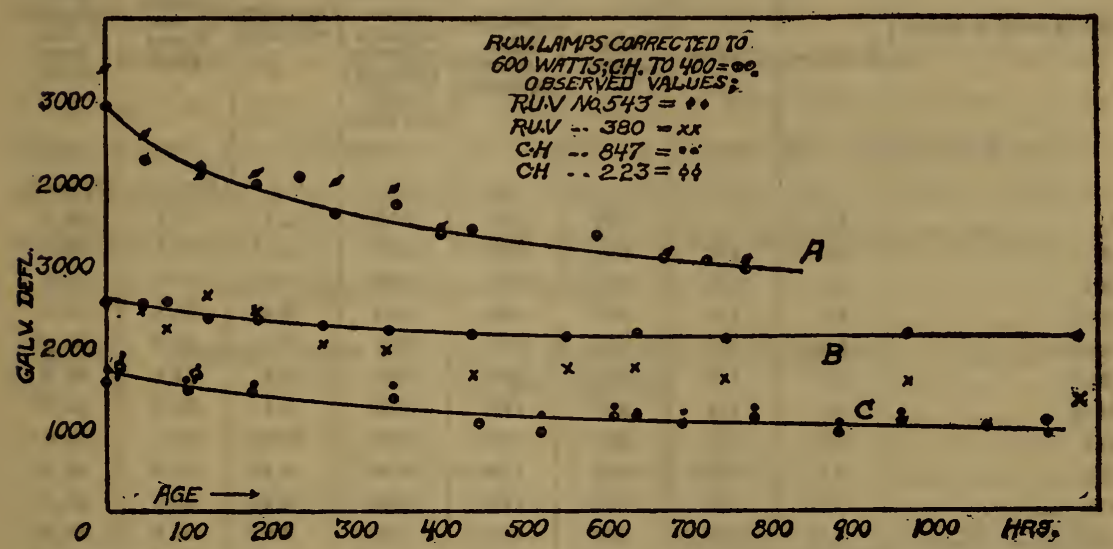

FIG. 6.-Decrease in radiation from quartz mercury vapor lamps with usage, as observed through a I cm cell of water, with glass windows

In the R. U. V. lamps tested, the end containing the positive electrode (tungsten target) became blackened over a length of 2 to $3 \mathrm{~cm}$ during the first 100 to 200 hours' operation. As a result there was at first a rather rapid decrease in the total radiation emitted, after which the total radiation continued slowly to decrease in intensity throughout the 1200 to 1500 hours during which the lamps were under observation, although the power input remained constant.

In one R. U. V. lamp (No. 380, Fig. 6) the power input as well as the total radiation continued to decrease with usage, and during the first 200 hours the ballast resistance was kept adjusted so that the lamp operated on 600 watts.

After 300 hours no further adjustments were made to the ballast resistance. This accounts for the large difference between the observed curve (crosses $x x, B$, Fig. 6 ) and the observations to be expected for a power input of 600 watts. These data are given in column 5 of Table 3 which gives the observed galvanometer deflections (intensity) and column 6 which gives these same deflections reduced to a power input of 600 watts. This lamp 
did not blacken rapidly with usage, and, if it had continued to operate on 600 watts, it would appear that, after 500 hours' usage, the total energy radiated, as well as the ultra-violet radiation, would have decreased very slowly with usage.

TABLE 3.-Radiant Power Life Test of Quartz Mercury Vapor Lamp, R. U. V. No. 380,220 Volt

\begin{tabular}{|c|c|c|c|c|c|c|c|c|}
\hline \multirow[b]{2}{*}{ Age of lamp in hours } & \multicolumn{3}{|c|}{ Power input } & \multicolumn{2}{|c|}{ Energy radiated } & \multirow[b]{2}{*}{$\begin{array}{l}\text { Operating } \\
\text { efficiency }\end{array}$} & \multirow[b]{2}{*}{$\begin{array}{c}\text { Trans- } \\
\text { mission } \\
\text { through } \\
\text { Noviol } \\
\text { glass }\end{array}$} & \multirow[b]{2}{*}{$\begin{array}{c}\text { Ultra- } \\
\text { violet } \\
\text { radiation } \\
\lambda \text { less } \\
\text { than } \\
0.45 \mu\end{array}$} \\
\hline & Amperes & Volts & $\begin{array}{l}\text { Watt- } \\
\text { meter }\end{array}$ & $\begin{array}{c}\text { Observed } \\
\text { galva- } \\
\text { nometer } \\
\text { deflection }\end{array}$ & $\begin{array}{c}\text { Observed } \\
\text { galva- } \\
\text { nometer } \\
\text { deflection } \\
\text { reduced } \\
\text { to } 600 \\
\text { watt input }\end{array}$ & & & \\
\hline & & & & $\mathrm{cm}$ & cm & & Per cent & Per cent \\
\hline $1.4 \ldots$ & 3.5 & $\cdots . .$. & 600 & 2572 & 2572 & 11.2 & 3.0 .2 & 66.4 \\
\hline $44 \ldots \ldots \ldots \ldots . .$. & 3.5 & 175 & $5+85$ & 2485 & 2576 & 11.15 & 32.1 & 64.4 \\
\hline $74.7 \ldots \ldots \ldots \ldots \ldots \ldots$ & 3.3 & 176 & 555 & 2279 & 25688 & 11.7 & 32.4 & 64.0 \\
\hline $124.3 . \ldots \ldots \ldots \ldots \ldots$ & 3.7 & 171 & 660 & 2690 & $\angle 395$ & g̀ 65 & 34.5 & 61.7 \\
\hline $185.4 \ldots \ldots \ldots \ldots \ldots$ & 3.5 & 178 & 615 & 2450 & 2375 & 10.0 & 34.8 & 61.3 \\
\hline $263.8 \ldots \ldots \ldots \ldots \ldots \ldots$ & 3.2 & 178 & 552 & 2040 & 2280 & 10.3 & 35.4 & 60.7 \\
\hline $342.8 \ldots \ldots \ldots \ldots$ & 3.1 & 177 & 540 & 1917 & 2220 & 9.8 & 35.5 & 60.6 \\
\hline $445 \ldots \ldots \ldots . .$. & 3.0 & 170 & 495 & 1650 & 2180 & 10.0 & 35.1 & 61.0 \\
\hline $561 \ldots \ldots \ldots \ldots . .$. & 3.0 & 176 & 510 & 1736 & 2170 & 9.76 & 35.0 & 61.0 \\
\hline $641 \ldots \ldots \ldots \ldots \ldots \ldots$ & 3.0 & 175 & 510 & 1750 & 2180 & 9.64 & 35.1 & 61.0 \\
\hline $749.1 \ldots . . \ldots \ldots \ldots . . . .$. & 3.0 & 169 & 507 & 1658 & 2098 & 9.02 & 35.6 & 60.4 \\
\hline $968 . . . . . . . . . . . . . .$. & 2.7 & 178 & 480 & 1556 & 2140 & 9.66 & 35.9 & 60.1 \\
\hline $1178 \ldots \ldots \ldots \ldots \ldots$ & 3.0 & 168 & 540 & $185 \delta$ & 2120 & 8.14 & 35.9 & 60.2 \\
\hline
\end{tabular}

TABLE 4.-Radiant-Power Life Test of Quartz Mercury Lamp, R. U. V. No. 543, 220 Volt

\begin{tabular}{|c|c|c|c|c|c|c|c|c|}
\hline \multirow[b]{2}{*}{ Age of lamp in hours } & \multicolumn{3}{|c|}{ Power input } & \multicolumn{2}{|c|}{ Energy radiated } & \multirow[b]{2}{*}{$\begin{array}{l}\text { Operating } \\
\text { efficiency }\end{array}$} & \multirow[b]{2}{*}{$\begin{array}{l}\text { Trans- } \\
\text { mission } \\
\text { through } \\
\text { Noviol } \\
\text { glass }\end{array}$} & \multirow[b]{2}{*}{$\begin{array}{c}\text { Oltra- } \\
\text { violet } \\
\text { radiation } \\
\lambda \text { less } \\
\text { than } \\
0.45 \mu\end{array}$} \\
\hline & Amperes & Volts & $\begin{array}{l}\text { Watt- } \\
\text { meter }\end{array}$ & $\begin{array}{c}\text { Observed } \\
\text { galva- } \\
\text { nometer } \\
\text { deflection }\end{array}$ & $\begin{array}{c}\text { Observed } \\
\text { galva- } \\
\text { nometer } \\
\text { deflection } \\
\text { reduced } \\
\text { to } 600 \\
\text { watt input }\end{array}$ & & & \\
\hline $0, \ldots \ldots \ldots, \ldots$ & 3.8 & 170 & 638 & $\begin{array}{c}\mathrm{cm} \\
3446\end{array}$ & $\begin{array}{c}\mathrm{cm} \\
2966\end{array}$ & 9.05 & $\begin{array}{c}\text { Per cent } \\
29.0\end{array}$ & $\begin{array}{c}\text { Per cent } \\
67.8\end{array}$ \\
\hline $50 \ldots \ldots \ldots \ldots \ldots \ldots . . . . . .$. & 3.9 & 165 & 636 & 2645 & 2296 & ......... & 32.8 & 63.6 \\
\hline $117 \ldots \ldots \ldots \ldots \ldots \ldots$ & 3.9 & 160 & 613 & 2109 & 2208 & ........ & 32.7 & 63.7 \\
\hline $185, \ldots \ldots \ldots \ldots \ldots \ldots$ & 3.6 & 170 & 618 & 2158 & 2015 & .......... & 32.2 & 64.2 \\
\hline $236 \ldots$ & 3.6 & 165 & 594 & 2032 & 2076 & & $\ldots . .$. & \\
\hline $280 \ldots \ldots \ldots \ldots \ldots$ & 4.5 & 145 & 652 & 2000 & 1620 & ........... & ............ & ........... \\
\hline $352 \ldots \ldots \ldots \ldots \ldots \ldots . . . . . .$. & 4.1 & 155 & 632 & 1960 & 1730 & 6.97 & $\ldots \ldots \ldots$ & .......... \\
\hline $409 \ldots \ldots \ldots$ & ….... & 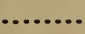 & 607 & 1486 & 1448 & $\ldots \ldots \ldots$ & 37.0 & 58.9 \\
\hline $446 \ldots \ldots \ldots \ldots \ldots$ & ....... & & 602 & 1491 & 1480 & ........... & 37.7 & 58.1 \\
\hline $593 . . . . . . . . .$. & & & 595 & 1301 & 1325 & & 39.0 & 56.7 \\
\hline $678 \ldots . . . \ldots \ldots \ldots \ldots . . .$. & $\ldots \ldots \ldots$ & & 618 & 1188 & 1100 & & 38.4 & 57.3 \\
\hline $724 \ldots \ldots \ldots \ldots \ldots$ & 4.2 & & 622 & 1098 & 1046 & ..... & ....... & $\cdots \cdots$ \\
\hline $739 \ldots \ldots \ldots \ldots$ & 4.7 & & 641 & 1170 & 994 & $\ldots \ldots$ & 38.4 & 57.3 \\
\hline $765 . \ldots \ldots \ldots \ldots \ldots$ & 4.2 & ......... & 617 & 1062 & 996 & 3.07 & 40.8 & 54.6 \\
\hline
\end{tabular}


Another R. U. V. lamp (curve A, Fig. 6 and Table 4) continued to operate on a fairly uniform energy input, but, in the course of 800 hours' operation, the energy emitted (galvanometer deflections) decreased to about one-third its original intensity.

In the $\mathrm{C}$. $\mathrm{H}$. lamps the constricted (negative) end becomes discolored with a brown deposit which reduces the intensity of the radiation rather rapidly during the first 200 hours. This deposit extends to the main part of the tube, with usage, and absorbs considerable ultra-violet radiation in spite of the fact that the coating is so thin that it imparts only a faint yellowish tinge to the lamp. This is illustrated in the lower curves, $C$, in Figs. 5 and 6 . Column 5 of Table 5 gives the observed galvanometer deflections (intensity) reduced to the same galvanometer sensitivity and column 6 gives these same deflections reduced to a uniform power input of 400 watts.

TABLE 5.--Radiant Power Life Test of Quartz Mercury Vapor Lamp, Cooper Hewitt No. 847, 220 Volt

\begin{tabular}{|c|c|c|c|c|c|c|c|c|}
\hline \multirow[b]{2}{*}{ Age of lamp in hours } & \multicolumn{3}{|c|}{ Power input } & \multicolumn{2}{|c|}{ Energy radiated } & \multirow[b]{2}{*}{$\begin{array}{l}\text { Operating } \\
\text { efficiency }\end{array}$} & \multirow[b]{2}{*}{$\begin{array}{c}\text { Trans- } \\
\text { mission } \\
\text { through } \\
\text { Noviol } \\
\text { glass }\end{array}$} & \multirow[b]{2}{*}{$\begin{array}{l}\text { Ultra- } \\
\text { violet } \\
\text { radiation } \\
\lambda \text { less } \\
\text { than } \\
0.45 \mu\end{array}$} \\
\hline & Amperes & Volts & $\begin{array}{l}\text { Watt- } \\
\text { meter }\end{array}$ & $\begin{array}{c}\text { Observed } \\
\text { galva- } \\
\text { nometer } \\
\text { deflection }\end{array}$ & $\begin{array}{l}\text { Observed } \\
\text { galvano- } \\
\text { meter } \\
\text { deflection } \\
\text { reduced } \\
\text { to } 400 \\
\text { watt input }\end{array}$ & & & \\
\hline & & & & cm & cm & & Per cent & Per cent \\
\hline $0 \ldots .$. & 3.0 & & 413 & 1735 & 1611 & 8.24 & 27.5 & 69.4 \\
\hline $97 \ldots$. & $\ldots$ & & 413 & 1612 & 1497 & $\ldots \ldots \ldots$ & 29.0 & 67.8 \\
\hline $177 \ldots .$. & ....... & $\cdots$ & 401 & 1511 & 1503 & ............ & 35.6 & 60.4 \\
\hline $343 \ldots .$. & ...... & & 416 & 1513 & 1380 & ........... & 35.6 & 60.4 \\
\hline $450 \ldots$ & ....... & & 401 & 1041 & 1033 & ............ & 36.1 & 59.9 \\
\hline $522 \ldots$ & 3.3 & & 439 & 1158 & 910 & ............. & 38.0 & 58.2 \\
\hline $615 \ldots$. & 2.8 & $\ldots .$. & 420 & 1282 & 1141 & ............ & 40.6 & 54.9 \\
\hline $640 \ldots \ldots \ldots \ldots \ldots \ldots$ & 3 & 142 & 413 & 1189 & 1104 & 4.87 & 40.6 & 54.9 \\
\hline $696.3 \ldots \ldots \ldots \ldots \ldots \ldots$ & 3.05 & 138 & 416 & 1136 & 1036 & ............. & 42.1 & 53.2 \\
\hline $783 . . . \ldots \ldots \ldots \ldots \ldots$ & 2.9 & 144 & 416 & 1214 & 1107 & 4.93 & 43.0 & 52.3 \\
\hline $886 \ldots . . . \ldots \ldots \ldots . . . .$. & 2.8 & 143 & 422 & 1052 & 925 & ............ & 43.8 & 51.2 \\
\hline $959 . \ldots \ldots \ldots \ldots \ldots \ldots$ & 2.8 & ........ & 397 & 1052 & 1069 & .............. & 44.3 & 50.8 \\
\hline $1064 \ldots \ldots \ldots$ & 2.9 & & 405 & 1054 & 1025 & 4.20 & 44.5 & 50.5 \\
\hline $1140 \ldots \ldots \ldots \ldots \ldots$ & 2.75 & 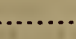 & 386 & 960 & 1034 & ............. & 45.8 & 49.1 \\
\hline
\end{tabular}

The radiometric data on radiant-power life tests of several quartz mercury vapor lamps are summarized in Table 6 . For some lamps, the tests are incomplete. However, from the data presented herewith, it is evident that the total radiation as well as the ultra-violet component decreases markedly with usage of quartz mercury vapor lamps. While the number of lamps are too 
few to form conclusions as to the general behavior of such lamps, the above-mentioned data indicate a decrease in intensity of onehalf to one-third the initial value in the course of 1000 to I 200 hours' operation.

TABLE 6.-Summary of Radiant-Power Life Tests of Quartz Mercury Vapor Lamps Giving the Decrease in Radiation from 0 to $1.4 \mu$ and in the Per Cent of Uitra-Violet Radiation with Age of Lamp; also the Power Input and Operating Efficiency

[Tests incomplete on several lamps]

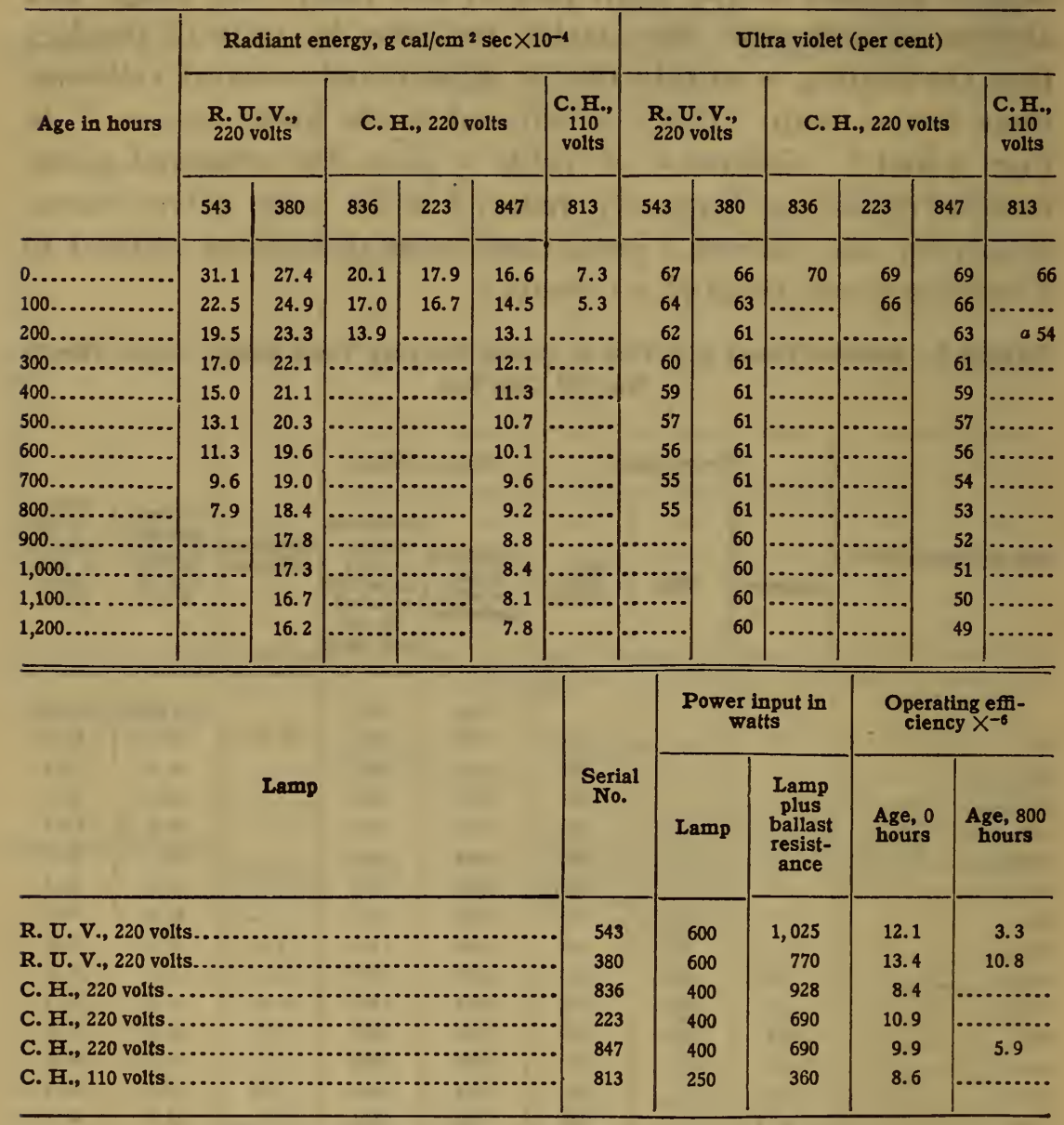

a Estimated age; actual time of operation of this lamp is unknown.

As already mentioned, the lamps (especially the R. U. V. type, which originally was designed for an entirely different purpose from the one mentioned in this paper) are operated at too high a temperature to obtain a fairly constant performance. As a result the useful life of the lamps, now obtainable, does not appear 
to be much greater than I000 to 1500 hours. Of course, the lamps are sometimes usable for several thousand hours, especially when operated continuously. However, the average laboratory lamp is not operated continuously.

By dispensing with the high intensity which is obtained on the rated normal operation, these lamps will not discolor nor devitrify so rapidly and their useful life can be greatly prolonged, without much loss in time in making the aforementioned tests.

\section{TOTAL RADIATION AND OPERATING EFFICIENCY OF QUARTZ MERCURY VAPOR LAMPS}

It is of interest to record, in absolute valiue, the total radiation of all wave lengths; also the radiation of wave lengths less than I. $4 \mu$, emitted by quartz-mercury vapor lamps.

The data given in column 6 of Tables 3,4 , and 5 may be reduced to energy in absolute value by multiplying the observed galvanometer deflections by the factor $\mathrm{I} \mathrm{cm}$ defl. $=2.2 \mathrm{I} \times 1 \mathrm{IO}^{-6}$ watt $=5.29 \times 10^{-7} \mathrm{~g}$-cal. per $\mathrm{cm}^{2}$ per sec.

The total radiation of all wave lengths from quartz-mercury vapor lamps is rather indefinite owing to the presence of the hood and other surroundings which become heated and emit radiations of long wave lengths. It was found that the $\mathrm{I} \mathrm{cm}$ water cell, with glass windows, transmitted from I4 to 15 per cent of the total radiation from these two types of lamps. From this, and from direct measurements, it was found that the total radiation of all wave lengths is about 7 times that indicated by the measurements given in column 6 of Tables 3,4 , and 5 or about o.or g-cal. per $\mathrm{cm}^{2}$ per sec. at $40 \mathrm{~cm}$ from the center of a new R. U. V. lamp. The 220-volt R. U. V. lamps, including ballast resistance, were operated on a power input which was about i 5 per cent greater than that used on the 220-volt C. H. lamps.

In order to determine the energy flux of wave lengths less than I. $4 \mu$ incident at a point $40 \mathrm{~cm}$ from the lamp (and equidistant from the ends as already described) it is necessary to correct the observations for absorption by the glass water cell. It was found that the $\mathrm{I} \mathrm{cm}$ water cell with quartz windows transmitted I.6 times ( $\mathrm{I} .3$ for an old lamp) as much mercury vapor radiation as did the $1 \mathrm{~cm}$ water cell having glass windows. Moreover, it was found that a I cm water cell having quartz windows transmitted 84 per cent of the mercury vapor radiations which had passed through a similar I cm water cell having quartiz windows. From 
this it would appear that the total radiation intensity of wave lengths less than $\mathrm{r} .4 \mu$, incident at $40 \mathrm{~cm}$ from these quartz mercury vapor lamps, when new, is $(\mathrm{r} .6 \div 0.84 \Rightarrow)$ r.9 times that indicated in column 6 of Tables 3,4 , and 5 . For lamps, operated rooo hours, this factor would be $(\mathrm{r} .3 \div 0.84=)$ r.55 instead of I.9. For intermediate intervals this decrease is taken to be uniform. Using these factors and the one for reducing the galvanometer deflections to gram-calories, the data in column 6 of Tables 3,4 , and 5 are given (for even intervals of 100 hours) in Table 6.

The energy of wave lengths less than $\mathrm{I} .4 \mu$ radiated by the R: U. V. lamps was probably 40 to 60 per cent greater (depending upon usage, etc., see Fig. 6 and Table 6) than that of the C. H. lamp. In the latter about 40 per cent of the applied energy is used in the ballast. This reduces the operating efficiency (ratio of energy radiated to energy input) as shown in the lower part of Table 6.

At the high energy input used, the voltage-current characteristics of the R. U. V. lamp is rather unstable so that there was constantly a great fluctuation in energy input. This caused great difficulty in making radiant energy measurements. This difficulty was not experienced with the C. H. lamp.

\section{COMPARATIVE DATA OF VARIOUS SOURCES OF RADIATION}

In view of the frequent inquiries for sources of ultra-violet radiation and the relative proportions of ultra-violet and visible radiations in various well-known sources of light, it is of interest to include comparative data in this paper.

Some years ago Bell ${ }^{15}$ determined the ultra-violet component of the radiations emitted by various artificial sources. It is of interest to note that he found that a Cooper-Hewitt glass mercury vapor lamp emits only about one-sixth as much ultra-violet as is found in a quartz mercury vapor lamp.

In Table 7 is given a comparison of the solar radiation for average air mass ( 2.7 for a ro-hour day) with the intensity at $40 \mathrm{~cm}$ from the axis and equidistant from the ends of the new 220-volit C. $\mathrm{H}$. quartz mercury vapor lamp; also the average tota 1 radiation of two new 220 volts $R$. U. V. lamps.

Radiometric Measurements On a Dye-Fading Carbon Arc Lamp.Tests were made also on a 220-volt arc lamp ${ }^{16}$ with "violet flame" carbon electrodes, used in dye-fading tests. The power input was about 4000 watts. 
TABLE 7.-Comparison of Solar Radiation with that of Quartz Mercury Vapor Lamp, C. H. 223

\begin{tabular}{|c|c|c|c|c|}
\hline \multirow[b]{2}{*}{ Wave length } & \multicolumn{2}{|c|}{ Solar radiation } & \multicolumn{2}{|c|}{$\begin{array}{l}\text { Quartz mercury } \\
\text { vapor radiation }\end{array}$} \\
\hline & $\begin{array}{c}\text { Gram- } \\
\text { calorie } \\
\text { per square } \\
\text { centimeter } \\
\text { per second }\end{array}$ & $\begin{array}{l}\text { Per cent } \\
\text { of total }\end{array}$ & $\begin{array}{c}\text { Gram- } \\
\text { calorie } \\
\text { per square } \\
\text { centimeter } \\
\text { per second }\end{array}$ & $\begin{array}{l}\text { Per cent } \\
\text { of total }\end{array}$ \\
\hline 0 to $0.45 \mu \ldots$ & 0.0008 & 5 & 0.0011 & 20 \\
\hline 0 to $1.4 \mu \ldots . . . . . .$. & .0129 & (......... & .0017 & 30 \\
\hline 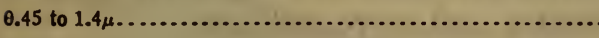 & .0121 & 78 & .0006 & 11 \\
\hline $1.4 \rho$ to $\infty \ldots \ldots \ldots \ldots \ldots . . . . .$. & .0026 & 17 & .0039 & 70 \\
\hline 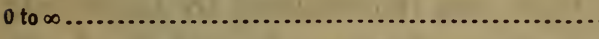 & .0155 & 100 & .0056 & 100 \\
\hline 0 to $\infty \ldots . .$. & & .... & a. 01 & 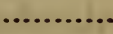 \\
\hline
\end{tabular}

DYE-FADING CARBON ARC

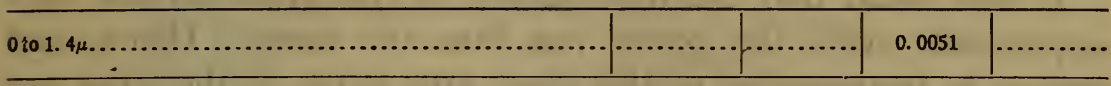

a R. U. V. lamp.

The total radiation intensity (of wave lengths less than $\mathrm{I} .4 \mu$ ) at a distance of $40 \mathrm{~cm}$ from the arc with the glass globe in place was about $5 . \mathrm{I} \times \mathrm{IO}^{-3} \mathrm{~g}$-cal. per $\mathrm{cm}^{2}$ per sec. The ultra-violet component of wave lengths less than $0.45 \mu$ (determined by means of the Noviol glass previously described) is about 59 per cent of the above-mentioned total radiation.

From this it appears that the ultra-violet component is practically the same as that of the quartz-mercury vapor lamp, while its total radiation is two to three times that of the mercury vapor lamps.

The power input is about five times that of the mercury vapor lamps. However, the increase in useful area surrounding the carbon arc, having approximately equal illumination, is about two and a half times that of the mercury arc. This increase in useful area compensates for the increased power input, so that the operating efficiency is practically the same for these two types of lamps. If a quartz mercury vapor lamp can be constructed so that it can be used in a vertical position, the operating efficiency can be more than doubled by utilizing the space entirely surrounding the axis of the burner.

\section{SUMMARY}

The object of the present investigation was, first, to devise methods for determining, quantitatively, the decrease in intensity of emission with usage and, second, to make preliminary measurements on radiant-power life tests of quartz mercury vapor lamps. 
The lamps used were made by the Cooper-Hewitt Electric Co. and by the R. U. V. Co. (Inc.).

This paper gives experimental data on the decrease in intensity of the ultra-violet and of the total radiation with usage of quartz mercury vapor lamps.

The intensities were measured radiometrically by means of a bismuth-silver thermopile and auxiliary galvanometer. A water cell $\mathrm{r} \mathrm{cm}$ in thickness with quartz windows was used in front of the thermopile to absorb the infra-red rays of long wave length, which are emitted by the electrodes and surroundings.

The decrease in ultra-violet rays was determined by observing the change in transmission of a yellow (Corning Noviol, shade B) glass, with usage of the lamps.

It was found that the transmission of this glass did not vary appreciably with the power put into the lamp. Hence, any change in transmission of this glass with usage of the lamp was ascribable to variations (decrease) in emission of ultra-violet rays caused by absorption in passing through the quartz glass tube, which becomes discolored with usage. By this means it was established that the ultra-violet rays, emitted from quartz mercury vapor lamps, decrease from an initial value of about 70 per cent (of the total radiation of wave lengths less than $1.4 \mu$ ) when the lamp is new' to about 50 per cent after rooo to i 500 hours' usage.

During the first 500 hours' usage no marked difference was observed in the per cent of ultra-violet emitted by these two types of lamps.

It was observed that the total radiation from these lamps decreased in intensity by one-half to one-third the initial value in the course of 1000 to 1200 hours.

Data are given ( $\mathrm{I}$ ) on the variation of the total radiation emitted by quartz mercury vapor lamps with variation in energy input, (2) on the variation of the intensity of the irradiation parallel with the axis of the lamp, and (3) on the variation of the intensity of the total radiation with distance from the lamp.

Comparative data are given on the ultra-violet component in the radiations from the sun, from quartz mercury vapor lamps, and also from a carbon arc lamp which is used in dye-fading tests.

WASHINGTON, June 8, I9i8. 